\title{
Deposit Money Banking Financing And Its Effect On Real Sector Output In Nigeria: Evidence From Trade And Agricultural Sectors
}

\author{
Oka Felix Arikpo \\ Department Of Banking \& Finance \\ University Of Calabar, Nigeria \\ Dr. Adesola W. Adebisi \\ Department Of Accountancy \\ Cross River University Of Technology, Nigeria
}

\begin{abstract}
This study examined the effects of deposit money banks financing on real sector output in Nigeria. The study specifically assessed the effect of private sector credit, interest rate spread, deposit mobilization and banks' holding of treasury bills on trade and agricultural sectors outputs in Nigeria. The data for the study were source from the CBN statistical bulletin for the period 1984 to 2015 . The exploratory design was combined with the ex-post facto research design; the data collection method was desk survey. The study used the Vector Error Correction Mechanism (VECM) for data analysis. Findings showed that jointly, deposit money banks financing have a long term significant effect on the trade sector but does not have any long run effect on the agricultural sector in Nigeria. Also, it was revealed that there is no short run causality running from PSC, DMB, DTB and INTS to agricultural sector output; however only INTS has short run causality with trade sector output. Lastly, interest rate spread has an inverse effect on the trade sector output but a positive effect on the agricultural sector output in Nigeria. The study therefore recommends that Deposit money banks should in addition to granting loans to farmers; monitor the use of such funds to avoid loan diversion and consequently poor agricultural sector performance. Also, Banks should employ research staff to conduct researches on modern approaches to effective real sector production and investments and should use the research findings to train her loan customers on the best production techniques as this will go a long way to enhance the real sector output. Lastly, the spread between lending and deposit rates should be narrowed to trigger savings and enhance banks' loan supply and real sector loan demand which consequently will boost productivity in the real sector.
\end{abstract}

Keywords: Stock Market liquidity, Foreign Portfolio Investment, Capital Market, Financial Market, Total New Issues, Foreign Capital Inflows.

\section{INTRODUCTION}

No economy can survive without a vibrant real sector. This is because of the role it plays in generating employment opportunities, building capacity, enhancing export and foreign exchange earnings and producing and distributing goods and services to meet the demand of the economy. The real sector could therefore be conceived as a vehicle that drives economic growth and development. According to Sanusi (2011), it is the sector where goods and services are produced through the combined utilization of raw materials and other production factors such as labour, land and capital. Broadly speaking, the real sector has been categorized into agriculture, industry, building and construction, and services (Stephen \& Olufemi, 2015). Agriculture can be further broken into crop production, livestock, forestry and fishing, while 
industry comprises crude petroleum and mineral gas, solid minerals and manufacturing. Services are made up of transportation, communication, utilities, real estate \& business service, education and health (Sanusi, 2011).

The survival or otherwise of the real sector is dependent on its ability to access finance. Finance is the life blood and soul of any business. No business can succeed without finance, as it is required to purchase raw materials, capital equipment, settle outstanding obligations and modernize or/and expand business operation (Ojong, Arikpo and Ogar, 2015). The whole production process revolves around finance, for instance, finance is used to buy raw materials, employ labour and purchase capital equipment which aids the conversion of these raw materials into finished goods which must be sold to generate finance. In fact, as important as oxygen to human, so is finance to businesses.

The repository of finance is the banking sector. The banking sector mobilizes finances from the surplus and idle sources and channels same (in form of loans) to the deficit but active units (Real sector) through the intermediation process (Chris, Bassey \& Arikpo, 2014). This is why banks are often referred to as financial intermediaries since they help to bridge the gap between borrowers and lenders by creating a market in two types of security, one for lenders and the other for borrowers (Nzotta, 2004). If banks cannot grant loans to the deficit economic units within its immediate operational environment, the real sector will not grow, deposits will not be made and the bank itself will be a loser, which may eventually result at its liquidation (Galac, 2001; Udoka, 2014 and Honohan, 1997).

From the foregoing, it becomes clear the interrelationship between banks and the real sector. While the real sector needs banks to fund their operations through the provision of loan facilities, banks need the real sector to borrow funds and in return pay interest as compensation for the risk of parting with funds.

The Nigerian real sector is bedevilled with many constraints ranging from financial constraint, explained by high lending rates, high collateral requirements, lack of adequate credit, traceable mainly to the reluctance of banks to extend credit to real sector operators for expansion and modernization of operation. Firms crave for survival as their products are considered to be sub-standard relative to foreign made goods. The high level of financial illiteracy of some real sector managers, the hike in exchange rate coupled with the unfriendly and unstable policies of government have added to inability of the sector to operate efficiently as the wheel that drives economic growth.

The poor state of the Nigerian infrastructure and the high taxes charged on firms have further resulted in high cost of production leading to high prices of substandard products and low patronage of locally made goods. This further reduces the output and/or productivity and the level of funds needed to finance the sector. These result in the use of crude and unsophisticated technology leading to the production of inferior goods and the patronage of foreign goods. This study is therefore design to examine the role of banks in the development of the real sector economy in Nigeria.

\section{OBJECTIVES OF THE STUDY}

The major objective of this study is to assess the effect of deposit money bank financing on real sector output in Nigeria using trade and agricultural subsectors. The study is specifically designed to examine:

i. $\quad$ The effect of private sector credit, interest rate spread, deposit mobilization and banks' holding of treasury bills on trade sector output in Nigeria; 
ii. The effect of private sector credit, interest rate spread, deposit mobilization and banks' holding of treasury bills on agricultural sector output in Nigeria.

This study is divided into five sections; closely following this section is section two, which reviews some theories and empirical literature of interest. Following section two immediately is section three, which captures the research methodology and includes, research design, and the method of estimation. Sector four is the data analyses and discussion and section five is the summary of findings, conclusion and recommendations

\section{THEORETICAL FRAMEWORK AND LITERATURE REVIEW}

\section{Theoretical Framework}

There are two major theories underlying the role of banks in real sector financing. They include the supply leading theory and financial repression hypothesis. The study will however be anchored on the supply leading theory.

\section{The Supply Led Finance Theory}

This theory was first developed by Patrick (1966), who "stressed that finance is one of the leading aspects of economic development". Supply led finance theory is growth inducing or growth induced, which means finance is the most significant factor for promoting economic development. The provision of funds through financial institutions to support the creation, transformation, expansion of industries and developmental projects is an element of the supply led theory.

Furthermore, the supply-led finance theory can simply be described as the establishment of financial institutions in some areas before their products and services are effectively demanded. In 1976, Pius Okigbo's financial review committee in Nigeria, with respect to rural banking schemes (BS) in 1977 and the introduction of community banking system in 1990 to help encourage savings mobilization and credit expansion were direct reactions to the supplyled finance theory. In this theory, finance is regarded as a means of promoting small enterprises. In this case, productive resources are often transferred from non-growth sectors to growth or modern sectors of the economy to boost entrepreneurial development in the economy. Access to supply-leading finance creates enabling financial environment for entrepreneurs to think big (Patrick, 1966).

\section{Financial Repression Hypothesis}

This is associated with the work of Mckinnon (1973) and Shaw (1973). The theory emphasizes that financial development would contribute most significantly to economic growth if the authorities were not to interfere in the operations of the financial institutions. According to the proponents of the theory, poor performance by banks and other financial institutions is thus often attributed to interest rate regulation, ceiling on deposit and loan rates and official guidelines pertaining to lending operations. Such interferences results in a low and often negative rate of return on financial assets and therefore inefficient savings mobilized and channeled into investment projects.

To this end, the theorists advocated a positive real interest rate and financial liberalization which would ensure an optimal financial structure for development as well as eliminating the fragmentation of market. It is on these premises that this study choose to base its theoretical framework on the financial repression hypothesis. 


\section{Review Of Empirical Literature}

Several studies abound on the relationship between banks lending activities and real sector performance. This section reviews a few of these studies, the methodologies and findings. Aliyu and Yusuf (2013) revealed with the aid of Ordinary Least Square (OLS) technique that financial sector development has remarkable impact on real sector growth. However, credit allocated to the private sector wields a significant impact while liquid liabilities and the size of financial intermediaries exert significant positive influence.

Udoh and Ogbuagu (2012) using an autoregressive distributed lag (ARDL) approach examined the relationship between financial sector development and industrial production between 1970 and 2009. The study discovered that financial sector development have significant adverse effect on industrial production.

Sendeniz-Yüncü, Akdeniz and Aydoğan (2006) evaluated whether credit-view hypothesis holds in 11 OECD countries from 1987Q1 to 2003Q3. The co-integration tests revealed that the banking sector and real sector are related in the long-run in all countries. The Granger causality tests provide strong evidence of the credit-view hypothesis (i.e. banking sector lead real sector) in some countries while no causality between both sectors in other countries.

Rasheed (2010) investigated the productivity in the Nigerian manufacturing subsector using co-integration and an error correction model. The study indicates the presence of a long-run equilibrium relationship index for manufacturing production, determinants of productivity, economic growth, interest rate spread, bank credit to the manufacturing subsector, inflation rates, foreign direct investment, exchange rate and quantity of graduate employment. This finding has research gap on the area of factors that affect manufacturing sector in Nigeria.

Sangosanya (2011) used panel regression analysis model and gibrat's law of proportionate effect in investigating firm's growth dynamics in Nigerian manufacturing industry. The study observed that the manufacturing firms finance mix, utilization of assets to generate more sales, abundance of funds reserve and government policies are significant determinants of manufacturing industry growth in Nigeria.

Charles (2012) investigated the performance of monetary policy on manufacturing sector in Nigeria, using econometrics test procedures. The result indicates that money supply positively affect manufacturing index performance while company lending rate, income tax rate, inflation rate and exchange rate negatively affect the performance of manufacturing sector. This means that monetary policy is vital for the growth of the manufacturing sector in Nigeria which in turn would lead to economic growth. The gap in this study is that the authors did not identify those factors that measure manufacturing sector performance like capacity utilization (output) and manufacturing share in GDP (input).

Loto (2012) examined the relationship between global economic meltdown and the manufacturing sector performance in the Nigerian economy using descriptive analysis and pooled data. The result indicates that the global economic meltdown has insignificant effect on the manufacturing sector of the Nigerian economy. These empirical findings support previous literature on economic growth but it failed to use t-test or statistics in testing pre and post global economic meltdown which is research gap.

Tomola, Adebisi and Olawale (2012) employed co-integration and vector error correction model (VECM) techniques to determine the link between bank lending, economic growth and manufacturing sector in Nigeria. The finding of the study revealed that manufacturing capacity 
utilization and bank lending rates significantly affect manufacturing output in Nigeria. This means that the growth of manufacturing output has not been enough to generate sizeable growth in the economy. The study has research gap in terms of not identifying relationship between manufacturing sector performance and economic growth in Nigeria.

Ikenna (2012) has employed time series data from 1970-2009 on an Autoregressive Distributed Lag (ARDL) - Based Test Model to test for the long and short run impact of financial deregulation and the possibility of a credit crunch in the real sector. The results suggest that deregulating the Nigerian financial system had an adverse boomerang effect on the credits allocated to the real sectors in the long run, and in the short run financial liberalization was in all insignificant and negative. Ikenna also concludes that Deposit Money Banks (DMBs) in Nigeria have strong discriminatory credit behaviour towards the real sector (agriculture and manufacturing) and the SMEs as credit crunch is found to be present in these sectors both in the short and long run

Tajudeen (2012) examined the relationship between commercial bank credits indicators and rural economic growth in Nigeria. Using a double-log equation within the context of Ordinary Least Square (OLS) framework and co-integration test, the study finds that rural economic growth is co-integrated with bank credits indicators in Nigeria. The study also revealed a positive relationship between rural economic growth and commercial banks rural loans as well as commercial bank loans to agricultural and rural economic growth.

Kar and Penecost (2000), using several proxies for financial development and economic growth, search for a cointegrating relationship between these variables over the period of 1963-1995 with annual data for Turkey. They estimate a vector error correction model for non-stationary variables and a cointegrated relationship. Their results reveal that all causal relationships between finance and growth depend on the measures of financial development. Although on balance the demand-following hypothesis is stronger. The proxies for bank deposit, private sector credit and domestic credit are all indicating that economic growth causes financial development. In all, their results are inconclusive.

Ogar, Enya \& Arikpo (2015) examined the contribution of deposit money banks credit on the growth of the agricultural sector in Nigeria between the periods 1988 to 2011. The study applied the ordinary least square multiple regression statistical technique and found that both deposit money banks loans and the agricultural credit guarantee scheme fund had a positive relationship with the output of the agricultural sector.

\section{RESEARCH METHODOLOGY}

Two designs were adopted for this study; the first was the exploratory design. This assisted us in reviewing the empirical literatures and the relevant theories for this study. Lastly, the study adopted the ex-post facto research design which was used in collecting the secondary data sources on the study's variables from the CBN statistical bulletin using desk survey from the period 1986 to 2015.

\section{Model Specification}

This study is anchored on the supply leading finance of Patrick (1966) as has been reviewed in section two of this paper. On the basis of this theory, the study used Private Sector Credit (PSC), Bank Deposit Mobilization (DMB), Banks' Holding of Treasury Bills (DTB) and Interest Rate Spread (INTS) to measure financial sector performance while real sector was measure by 
Trade Sector Output (TRAO) and Agricultural Sector Output (AGRO). Hence, the functional relationship between the variables is expressed functionally thus:

$$
\begin{aligned}
\text { TRAO } & =\mathrm{f}(\text { PSC }, \text { DMB, DTB }, \text { INTS }) \\
\text { AGRO } & =\mathrm{f}(\text { PSC }, \text { DMB, DTB }, \text { INTS })
\end{aligned}
$$

The above relationship can be expressed econometrically using the following equations and in their log form to capture for the variables elasticity:

$$
\begin{aligned}
& \text { InTRAO }=a_{0}+b_{1} \operatorname{InPSC}+b_{2} \text { InDMB }+b_{3} \operatorname{InDTB}+b_{4} \text { INTS }+e_{t} \\
& \text { InAGRO }=b_{0}+d_{1} \operatorname{InPSC}+d_{2} \text { InDMB }+d_{3} \operatorname{InDTB}+d_{4} \text { INTS }+e_{t}
\end{aligned}
$$

Note: TROA, PSC, DMB, DTB, INTS maintain their initial meaning as have been explained above. The a priori expectation about the signs of the parameters of the independent variables is stated thus: $b_{1}, b_{2}, b_{3}>0 ; b_{4}<0$.

\section{Estimation Techniques}

We analysed the properties of the data using the descriptive statistics. The study also used the Augmented Dickey Fuller (ADF) unit root test to examine the stationarity property of the data set. The ADF model is specified thus:

$$
\nabla y_{t}=y_{0}+y_{1 t}+(\beta-1) y_{t-1}+\delta_{1} \Delta y_{t-1}+\varepsilon_{t}
$$

If the variables are integrated of the same order, we will proceed to test for co-integration using the Johansen-Jesulius multivariate co-integration approach thus:

$$
\Delta X_{t}=\sum_{I=1}^{P-1} \Gamma_{I} \Delta X_{T-I}+\Pi X_{\mathrm{t}-1}+\varepsilon_{t}
$$

Where:

$\mathrm{Xt}=5 \mathrm{x} 2$ Vector

$\Delta=$ Difference operator

$€_{\mathrm{t}}=5 \times 2$ Vector of Residuals

$\Gamma$ and $\Pi=$ estimated parameters

$\Pi \mathrm{X}_{\mathrm{t}-1}=$ Error correction term

If there is evidence of co-integration in the model, then a valid error correction model also exist among the variables of model, meaning that we will proceed to run an error correction model. Since we have more than one endogenous variable, the Vector Error Correction Model (VECM) will be estimated thus:

$\Delta \operatorname{InTRAO} O_{t}=\sum_{I=1}^{P=1} \beta_{I} \operatorname{In} \Delta T R A O_{t-1}+\sum_{I=1}^{P=1} \alpha_{I} \Delta \operatorname{InPSC} C_{t-1}+\sum_{I=1}^{P=1} \lambda_{1} \Delta \operatorname{InD} M B_{t-1}+$ $\sum_{I=1}^{P=1} \varphi_{1} \Delta I n B P R F_{t-1}+\sum_{I=1}^{P=1} \Omega_{1} \Delta I N T S_{t-1}+$

$\Delta \operatorname{InAGRO} O_{t}=\sum_{I=1}^{P=1} \tau_{I} \operatorname{In} \Delta A G R O_{t-1}+\sum_{I=1}^{P=1} \rho_{I} \Delta \operatorname{InPSC} C_{t-1}+\sum_{I=1}^{P=1} Z_{1} \Delta \operatorname{InDM} B_{t-1}+$ $\sum_{I=1}^{P=1} \mu_{1} \Delta I n B P R F_{t-1}++\sum_{I=1}^{P=1} \gamma_{1} \Delta I N T S+Z 2^{*} E C M 2_{t-1}+$ $e_{2 t}$

Where:

$ß_{1}, \alpha_{I}, \lambda_{1}, \varphi_{1}, \Omega_{1}, \tau_{I}, \rho_{I}, Z_{1}, \mu_{1}$ and $\gamma_{1}=$ Short Run Coefficient

ECM1 and ECM2 = Error Correction Terms

$\mathrm{e}_{1 \mathrm{t}}$ and $\mathrm{e}_{2 \mathrm{t}}=$ Residuals in equations (7) and (8) 
ECM1 $1_{\mathrm{t}-1}=$ Lagged Valued of the Residuals Derived from the Co-integration Regression of PSC, DMB, DTB and INTS on INDO

$\mathrm{ECM} 2_{\mathrm{t}-1}=$ Lagged Valued of the Residuals Derived from the Co-integration Regression of PSC, DMB, DTB and INTS on AGRO

Negative and significant $\mathrm{ECM} 1_{\mathrm{t}-1}$ and $\mathrm{ECM} 2_{\mathrm{t}-1}$ coefficient imply that there is no long run causality from the independent variables, PSC, DMB, DTB and INTS to the dependent variables TRAO and AGRO. The short run causality from the independent variables to the dependent variables will also be tested using the Wald test statistics.

To validate the stability of the estimates, the CUSUM test and the histogram normality test were apply. Furthermore, the study applied the Breusch-Godfrey serial correlation LM test to test whether or not the estimates of the model are interdependent and lastly, the study checked the heteroskedasticity of the model with the help of the Breusch-Pagan-Godfrey test.

\section{DATA ANALYSES AND DISCUSSION}

TABLE 1:DESCRIPTIVE STATISTICS

\begin{tabular}{lcccccc}
\hline & LTRAO & LAGRO & LPSC & LDMB & LDTB & \multicolumn{1}{c}{ INTS } \\
\hline Mean & 6.339169 & 6.786229 & 5.908660 & 5.008843 & 4.157756 & 10.02371 \\
Median & 6.756735 & 7.201201 & 5.863518 & 4.853592 & 3.845883 & 12.69000 \\
Maximum & 9.799731 & 9.885169 & 9.834895 & 8.678206 & 7.564083 & 20.70000 \\
Minimum & 2.524928 & 2.836150 & 2.148268 & 1.589235 & -0.105361 & -0.250000 \\
Std. Dev. & 2.440973 & 2.386299 & 2.567271 & 2.468343 & 2.388789 & 5.719128 \\
Skewness & -0.210524 & -0.266756 & 0.077908 & 0.094980 & -0.113081 & -0.331018 \\
Kurtosis & 1.667329 & 1.621342 & 1.672030 & 1.626289 & 1.488526 & 1.830699 \\
Jarque-Bera & 2.848555 & 3.186942 & 2.607185 & 2.804619 & 3.406234 & 2.633103 \\
Probability & 0.240682 & 0.203219 & 0.271555 & 0.246028 & 0.182115 & 0.268058 \\
Sum & 221.8709 & 237.5180 & 206.8031 & 175.3095 & 145.5214 & 350.8300 \\
Sum Sq. Dev. & 202.5838 & 193.6104 & 224.0899 & 207.1523 & 194.0147 & 1112.086 \\
Observations & 35 & 35 & 35 & 35 & 35 & 35 \\
\hline
\end{tabular}

Source: Researchers' Eview 9.1 Computation, 2017

We begin this section by examining the descriptive properties of the data set as found in Table1 above. From the table, the mean values of LTRAO, LAGRO, LPSC, LDMB, LDTB and INTS are respectively $6.3391,6.7862,5.9086,5.0088,4.1577$ and 10.0237 and their standard deviations are respectively 2.4409, 2.3862, 2.5672, 2.4683, 2.3887 and 5.7191 ranging respectively from 2.5249 to $9.7997,2.8361$ to $9.8851,2.1482$ to $9.8349,1.5892$ to 8.6782 and 0.1053 to 7.5640 .

An examination of the skewness of the data set as shown in table 1 revealed that LTRAO, LAGRO, LDTB and INTS were negatively skewed (left skewed distribution), meaning that their means are also to the left of the peak while LPSC and LDMB were skewed to the right meaning that their means are also peak to the right. Kurtosis is a measure of the peakedness of the data relative to the normal distribution. The coefficient of the kurtosis of the variables indicates that TRAo, AGRO, PSC, DMB, DTB and INTS were platykurtic below 3.000000 relative to the normal, meaning that the distribution produces fewer and less extreme outliers than does the normal distribution. 
The Jarque-Bera (JB) test statistics measures the difference of the skewness and kurtosis of the series with those from the normal distribution. The JB values of 2.8485, 3.1869, 2.6071, 2.8046, 3.4062 and 2.6331 for LTRAO, LAGRO, LPSC, LDMB, LDTB and INTS respectively with their respective p-values of 24.06 percent, 20.32 percent, 27.15 percent, 24.60 percent 18.21 percent and 26.80 percent showed that the data set is normally distributed.

TABLE 2: AUGMENTED DICKEY FULLER (ADF) UNIT ROOT TEST

\begin{tabular}{ccrc}
\hline Variables & \multicolumn{2}{c}{ ADF Test Statistics } & Order of integration \\
\cline { 2 - 3 } & Level & $1^{\text {st }}$ Difference & \\
\hline LTRAO & -1.181681 & -3.705960 & $\mathrm{I}(1)$ \\
LAGRO & -1.631241 & -3.773321 & $\mathrm{I}(1)$ \\
LPSC & -0.097333 & -4.209474 & $\mathrm{I}(1)$ \\
LDMB & -0.213309 & -3.948575 & $1(1)$ \\
LDTB & -0.356451 & -3.075051 & $\mathrm{I}(1)$ \\
INTS & -1.315277 & -7.070954 & $1(1)$ \\
\hline
\end{tabular}

Test critical values at level: $1 \%=-3.639407,5 \%=-2.951125,10 \%=-2.614300$

Test critical values at $1^{\text {st }}$ Diff: $1 \%=-3.646342,5 \%=-2.954021,10 \%=-2.615817$

Source: Researchers' Eview 9.1 Computation, 2017.

Table 2 showed that all the variables have unit root at levels but after differencing one time they all became stationary. This is so as the test statistics at levels, taking their absolute values were less than their critical values at 5 percent. However, after differencing one time, the test statistics, taking their absolute values became greater than their critical values at 5 percent level. Since the variables are integrated of the same order, we have to run a co-integration test using the Johansen co-integration test.

TABLE 3: VAR LAG ORDER SELECTION CRITERIA

Endogenous variables: LTRAO LAGRO LPSC LDMB LDTB INTS

\begin{tabular}{ccccccc}
\hline \hline Lag & LogL & LR & FPE & AIC & SC & HQ \\
\hline \hline 0 & -160.5090 & NA & 0.000972 & 10.09146 & 10.36355 & 10.18301 \\
1 & 8.260292 & 265.9395 & $3.24 \mathrm{e}-07$ & 2.044831 & $3.949477^{*}$ & 2.685686 \\
2 & 55.76663 & $57.58344^{*}$ & $2.03 \mathrm{e}-07^{*}$ & $1.347477^{*}$ & 4.884676 & $2.537637^{*}$ \\
\hline \hline
\end{tabular}

* indicates lag order selected by the criterion

LR: sequential modified LR test statistic (each test at 5\%

level)

FPE: Final prediction error

AIC: Akaike information criterion

SC: Schwarz information

criterion

HQ: Hannan-Quinn information criterion

From table 3, the optimum lag selection for this study using the Akaike Information Criterion is two meaning that our analyses will be lagged two times. 


\section{COINTEGRATION TEST}

TABLE 4a: UNRESTRICTED CO-INTEGRATION RANK TEST (TRACE)

\begin{tabular}{|c|c|c|c|c|}
\hline $\begin{array}{l}\text { Hypothesized } \\
\text { No. of CE(s) }\end{array}$ & Eigenvalue & $\begin{array}{c}\text { Trace } \\
\text { Statistic }\end{array}$ & $\begin{array}{c}0.05 \\
\text { Critical Value }\end{array}$ & Prob.** \\
\hline None* & 0.863572 & 161.7010 & 95.75366 & 0.0000 \\
\hline At most $1^{*}$ & 0.742408 & 97.95820 & 69.81889 & 0.0001 \\
\hline At most $2^{*}$ & 0.630108 & 54.55410 & 47.85613 & 0.0103 \\
\hline At most 3 & 0.410781 & 22.72868 & 29.79707 & 0.2596 \\
\hline At most 4 & 0.138752 & 5.802070 & 15.49471 & 0.7188 \\
\hline At most 5 & 0.031437 & 1.022146 & 3.841466 & 0.3120 \\
\hline
\end{tabular}

Trace test indicates 3 cointegrating eqn(s) at the 0.05 level Source: Researchers' Eview 9.1 Computation, 2017.

TABLE 4b: UNRESTRICTED CO-INTEGRATION RANK TEST (MAXIMUM EIGENVALUE)

\begin{tabular}{ccccc}
\hline \hline Hypothesized & & Max-Eigen & 0.05 & \\
No. of CE(s) & Eigenvalue & Statistic & Critical Value & Prob.** $^{*}$ \\
\hline \hline None ${ }^{*}$ & 0.863572 & 63.74276 & 40.07757 & 0.0000 \\
At most 1 & 0.742408 & 43.40410 & 33.87687 & 0.0027 \\
At most 2 & 0.630108 & 31.82542 & 27.58434 & 0.0134 \\
At most 3 & 0.410781 & 16.92661 & 21.13162 & 0.1755 \\
At most 4 & 0.138752 & 4.779924 & 14.26460 & 0.7693 \\
At most 5 & 0.031437 & 1.022146 & 3.841466 & 0.3120 \\
\hline \hline
\end{tabular}

Max-eigenvalue test indicates 3 cointegrating eqn(s) at the 0.05 level Source: Researchers' Eview 9.1 Computation, 2017

The co-integration test results as presented in table $4 \mathrm{a}$ and $\mathrm{b}$ indicate that there are thre cointegrating equations in the model. The values of the test statistics in the three co-integration equations for both trace test and maximum eigenvalues are found to be greater than their critical values at 5 percent significance level. Also, the p-values of the co-integrating equations are less than 5 percent meaning that the variables share a common stochastic trend and will grow proportionally. In other words, the move together in the long run meaning that they have long run association. 
TABLE 5: NORMALIZED COEFFICIENT (STANDARD ERROR IN PARENTHESES)

\begin{tabular}{cccccc}
\hline LTRAO & LAGRO & LPSC & LDMB & LDTB & INTS \\
\hline 1.000000 & \multirow{2}{*}{0.000000} & -5.111421 & 4.623811 & -0.303871 & -0.005142 \\
& & $(0.37691)$ & $(0.39150)$ & $(0.12557)$ & $(0.03386)$ \\
0.000000 & \multirow{2}{*}{1.000000} & -5.461001 & 5.255590 & -0.735384 & 0.068515 \\
& & $(0.48423)$ & $(0.50297)$ & $(0.16133)$ & $(0.04350)$ \\
\hline
\end{tabular}

Source: Researchers' Eview 9.1 Computation, 2017

Table five above is the long run coefficient of the causality running from private sector credit, deposit mobilization, deposit money banks holding of treasury bills, interest rate spread to agricultural sector output and trade sector output in Nigeria. From the table, private sector credit has an inverse effect on agricultural and trade sector output in the long run. In other words, when private sector credit goes up by one percent, trade sector output goes down by 5.11 percent in the long run. Similarly, when private sector output goes up by one percent, agricultural sector output goes down by 5.46 percent in the long run. This negates the a priori expectations. Theoretically, it is expected that the higher the credit to the private sector, all things being equal, the higher the productivity of the real sector.

Again there is a positive and direct relationship between deposit mobilization and trade sector and agricultural sector outputs as theoretically expected. When banks mobilize deposit, more loans are granted to real sector (agricultural sector and trade sector); these loans are put into productive uses. The result is an increase output. Accordingly, the table shows that a one percent increase in deposit mobilization by the financial sector led to a 4.62 percent and 5.25 percent increase in the output of the agricultural and trade sectors in the long run respectively. Furthermore, deposit money banks holding of treasury bills has negative influences on trade and agricultural sectors outputs in the long run. In other words, an increase in deposit money banks holding of treasury bills, a decrease in the outputs of the trade and agricultural sectors in Nigeria in the long run. This is not in tandem with the a priori expectations. Treasury bills are short term instrument which maturity spans the period of three month, hence, in the long term the instrument would have matured. So banks would have sufficient funds to lend to the real sector for investment purposes, which should result in an increase in productivity in the long run period. However, from the result, a one percent increase in deposit money banks holding of treasury bills, led to 3.03 percent and 7.35 percent decreases in trade and agricultural sector outputs in Nigeria

Finally, table 5 shows that interest rate spread has an inverse relationship with trade sector output, as expected but a positive relationship with the agricultural sector, against the theoretical expectations. From the result, a one percent increase in the spread between lending rate and deposit rate led to a 0.51 percent decrease in the output of the trade sector. When banks increase their lending rate relative to the deposit rate, it discourages borrowing, which in turn discourages the productivity of the real sector. Also, the result shows that a one increase in the spread between lending and deposit rates, led to a 6.85 percent increase in the output of the agricultural sector in Nigeria. 
TABLE 6: LONG RUN ERROR CORRECTION ANALYSIS Dependent Variable: LTRAO

Dependent Variable: LAGRO

\begin{tabular}{llll|llll}
\hline Variables & Coefficient & t-stats & p-value & Variables & Coefficient & t-stats & p-values \\
\hline $\mathrm{C}(1)$ & -0.5960 & -2.4265 & $0.0274^{*}$ & $\mathrm{C}(17)$ & -0.1322 & -0.4825 & 0.6360 \\
$\mathrm{R}^{2}$ & 0.6307 & & & $\mathrm{R}^{2}$ & 0.6281 & & \\
F-Statistics & 1.8220 & & 0.1225 & F-Statistics & 1.8016 & & 0.1269 \\
\hline
\end{tabular}

*Represents rejection of null hypothesis at 5 percent level Source: Researchers' Eview 9.1 Computation, 2017.

The study having estimated the VECM proceeded to make system equations to view the probabilities of the estimates. C (1) and C (17) are the error correction terms; they measure the speed of adjustment of trade sector output and agricultural sector output toward long run equilibrium. The expectation about error terms is that they must be negative and significant at 5 percent level. From the result above, C (1) is negative and significant at 5 percent level; meaning that there is a long run causality running from PSC, DMB, DTB and INTS to TRAO. Also, $C$ (17) is negative but insignificant at 5 percent level meaning that there is no long run causality from PSC, DMB, DTB and INTS to AGRO. This implies that PSC, DMB, DTB and INTS do not jointly cause AGRO in Nigeria in the long run.

Furthermore, the $\mathrm{R}^{2}$ value 0.6307 or 63.07 percent showed that about 63.07 percent of the observed behaviour of trade sector output has been explained by the joint variations of PSC, DMB, DTB and INTS. Also, the $\mathrm{R}^{2}$ value of 0.0 .6281 or 62.81 percent showed that about 62.81 percent of the observed changes in agricultural sector output have been explained by the variations in PSC, DMB, DTB and INTS. The F-statistics values of 1.8220 with it corresponding probability of 12.25 percent shows that the TRAO model is statistically insignificant, also, the F-statistics value of 1.8016 with it corresponding p-value of 12.69 percent shows that the AGRO model is not statistically significant at 5 percent level.

TABLE 7: BREUSCH-GODFREY SERIAL CORRELATION LM TEST FOR PSC, DMB, DTB INTS AND TRAO EQUATION

\begin{tabular}{llll}
\hline \hline F-statistic & 0.082982 & Prob. F(2,14) & 0.9208 \\
Obs*R-squared & 0.374900 & Prob. Chi-Square(2) & 0.8291 \\
\hline \hline
\end{tabular}

Source: Researchers' Eview 9.1 Computation, 2017.

Checking the observed $\mathrm{R}^{2}$ value of 0.3749 with it corresponding prob. Chi-square (2) of 82.91 percent, we conclude that the model is free from serial correlation.

TABLE 8: HETEROSKEDASTICITY TEST: BRUEUSCH-PAGAN-GODFREY FOR PSC, DMB, DTB INTS AND TRAO EQUATION

\begin{tabular}{llll}
\hline \hline F-statistic & 1.718595 & Prob. F(18,13) & 0.1619 \\
Obs*R-squared & 22.53140 & Prob. Chi-Square(18) & 0.2092 \\
Scaled explained SS & 2.962403 & Prob. Chi-Square(18) & 1.0000 \\
\hline \hline
\end{tabular}

Source: Researchers' Eview 9.1 Computation, 2017. 
From the table the observed $\mathrm{R}^{2}$ value of 22.5314 with it corresponding prob. Chi-square value of 20.92 percent, more than five percent, implies that the model is free from heteroskedasticity.

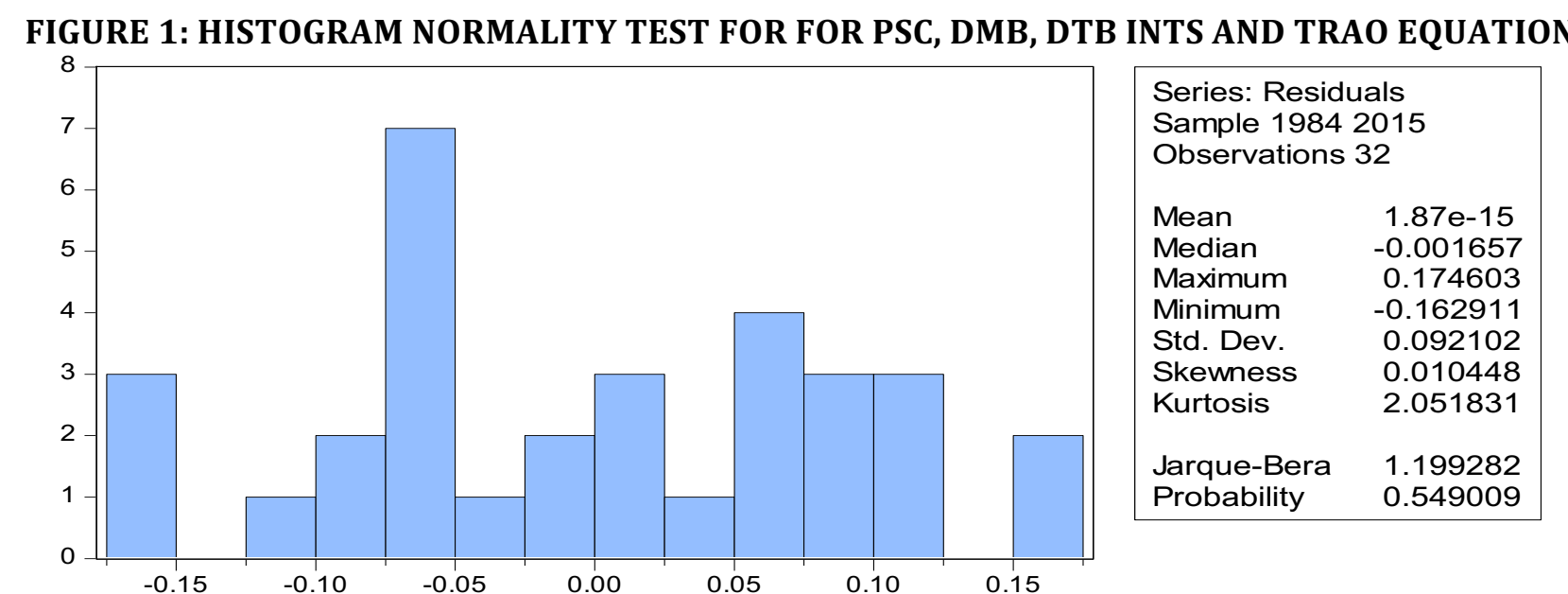

Source: Researchers' Eview 9.1 Computation, 2017.

The Jarque Bera statistics of 1.1992 with it corresponding probability of 54.90 percent, more than 5 percent, means that the residual of PSC, DMB, DTB, INTS AND TRAO equations is normally distributed.

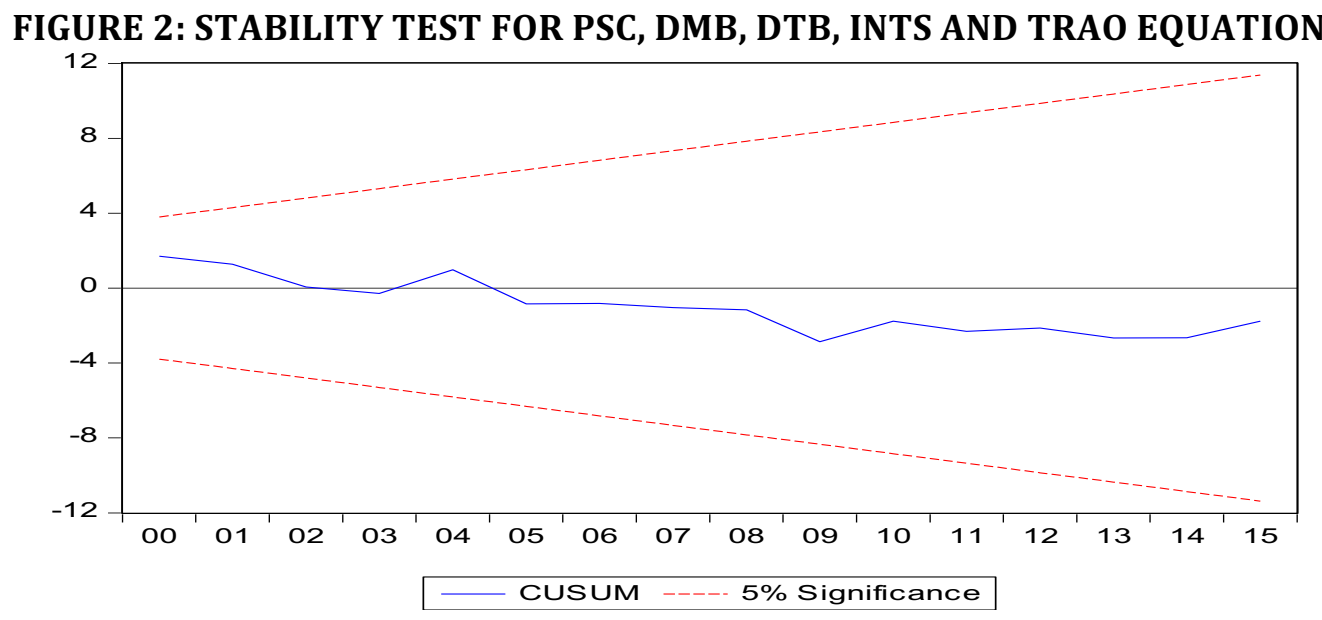

Source: Researchers' Eview 9.1 Computation, 2017.

From the CUSUM Test result, it could be seen that the blue line lies in between the two red lines. This means that the estimates of our PSC, DMB, DTB, INTS AND TRAO equation are stable and reliable.

TABLE 9: BREUSCH-GODFREY SERIAL CORRELATION LM TEST FOR PSC, DMB, DTB, INTS AND AGRO EQUATION

\begin{tabular}{llll}
\hline \hline F-statistic & 0.376257 & Prob. F(2,14) & 0.6932 \\
Obs*R-squared & 1.632293 & Prob. Chi-Square(2) & 0.4421 \\
\hline \hline
\end{tabular}

Source: Researchers' Eview 9.1 Computation, 2017.

From table 9, the observed $\mathrm{R}^{2}$ value is 1.6322 and it corresponding prob. Chi-square (2) is 44.21 percent. Since the prob. chi-square (2) value is greater than 5 percent, we conclude that the DMB, DTB, INTS AND AGRO equation has no serial correlation. 
TABLE 10: HETEROSKEDASTICITY TEST: BRUEUSCH-PAGAN-GODFREY FOR PSC, DMB, DTB, INTS AND AGRO EQUATION

\begin{tabular}{llll}
\hline \hline F-statistic & 0.850829 & Prob. F(18,13) & 0.6323 \\
Obs*R-squared & 17.30810 & Prob. Chi-Square(18) & 0.5020 \\
Scaled explained SS & 3.576724 & Prob. Chi-Square(18) & 0.9999 \\
\hline
\end{tabular}

Source: Researchers' Eview 9.1 Computation, 2017.

From the table, the observed $\mathrm{R}^{2}$ value of 17.3081 with it corresponding prob. Chi-square value of 50.20 percent, more than five percent, implies that the model is free from heteroskedasticity.

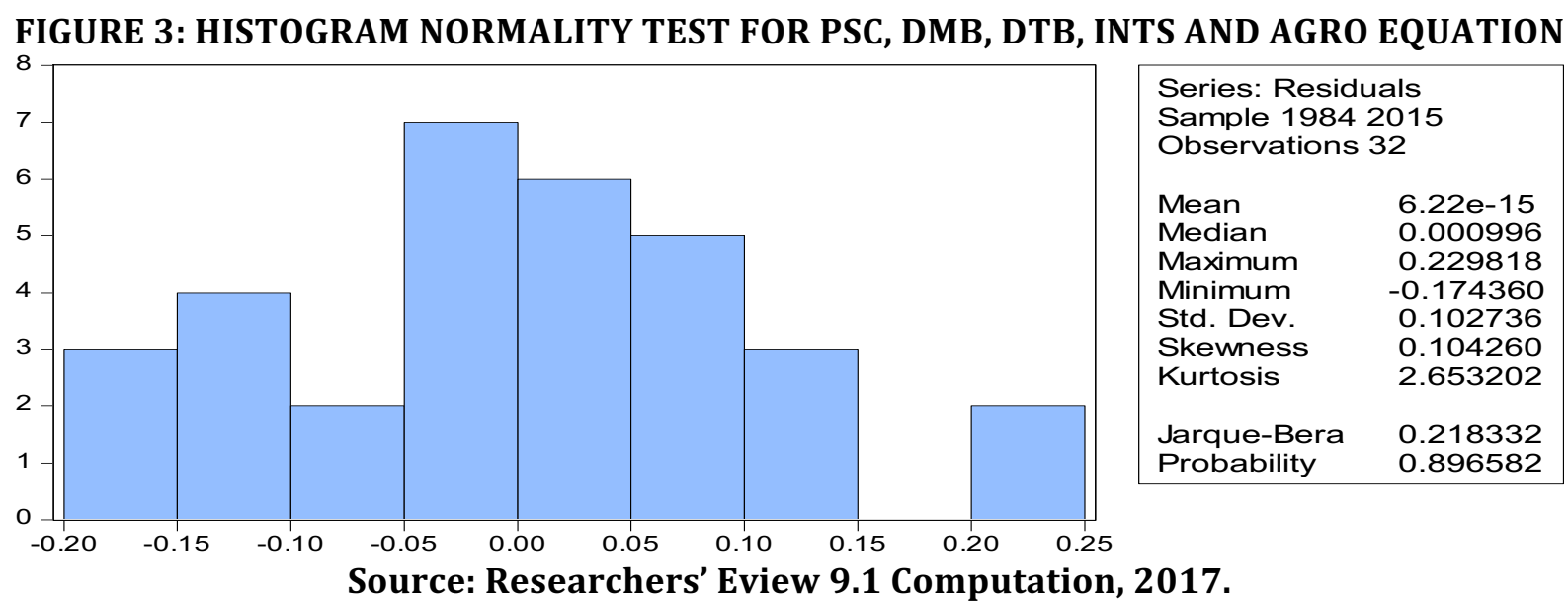

The Jarque Bera statistics of 0.2183 with it corresponding probability of 89.85 percent, greater than 5 percent, implies that the residual of the relationship between DMB, DTB, INTS AND AGRO equation is normally distributed.

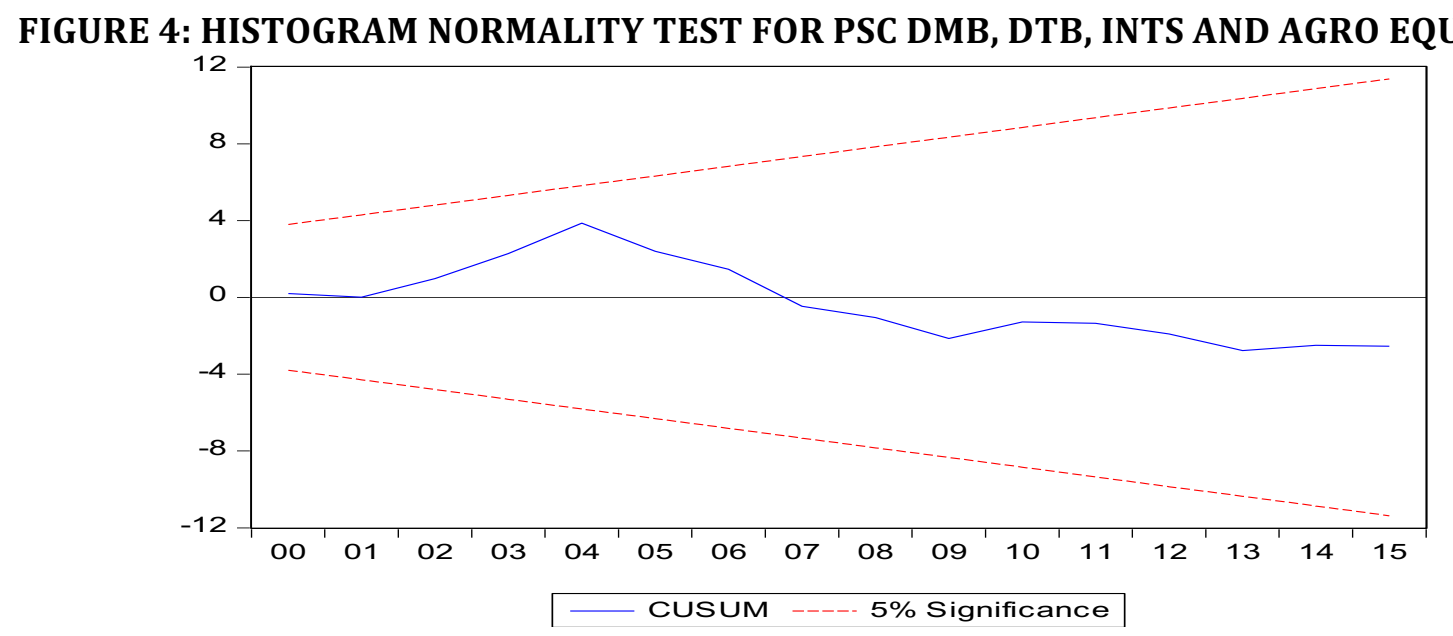

Source: Researchers' Eview 9.1 Computation, 2017.

From the CUSUM Test result, it could be seen that the blue line lies in between the two red lines. This means that the estimates of our PSC, DMB, DTB, INTS and AGRO relationship are stable and reliable. 
TABLE 11: ANALYSIS OF THE SHORT RUN CAUSALITY USING WALD TEST

\begin{tabular}{|c|c|c|c|c|c|c|c|}
\hline \multicolumn{4}{|c|}{ Dependent Variable: TRAO } & \multicolumn{4}{|c|}{ Dependent Variable: AGRO } \\
\hline $\begin{array}{c}\text { Null } \\
\text { Hypotheses }\end{array}$ & $\begin{array}{l}\text { Finance } \\
\text { Perfom } \\
\text { Indices }\end{array}$ & F-Stats & Prob. & $\begin{array}{c}\text { Null } \\
\text { Hypotheses }\end{array}$ & $\begin{array}{l}\text { Finance } \\
\text { perfom } \\
\text { Indices }\end{array}$ & F-Stats & Prob. \\
\hline$C(8)=C(9)=0$ & PSC & 0.2515 & 0.3931 & $C(24)=C(25)=0$ & PSC & 0.8595 & 0.4420 \\
\hline$C(10)=C(11)=0$ & DMB & 0.6169 & 0.5519 & $C(26)=C(27)=0$ & DMB & 1.5380 & 0.2449 \\
\hline$C(12)=C(13)=0$ & DTB & 0.9906 & 0.3930 & $C(28)=C(29)=0$ & DTB & 0.9107 & 0.4221 \\
\hline$C(14)=C(15)=0$ & INTS & 3.9761 & $0.039 *$ & $C(30)=C(31)=0$ & INTS & 0.3840 & 0.6872 \\
\hline
\end{tabular}

*Represents rejection of null hypotheses at 5 percent level Source: Researchers' Eview 9.1 Computation, 2017.

Table 8 only rejected the null hypotheses for the short run causality between interest rate spread and trade sector output, meaning that there is short run causality running from interest rate spread to trade sector output in Nigeria.

\section{SUMMARY OF FINDINGS}

The following major findings were made from our analyses:

i. $\quad$ Private sector credit and deposit money banks holding of treasury bills have inverse relationships with trade and agricultural sector output in Nigeria;

ii. Banks deposit mobilization has a positive effect on trade and agricultural sector output in the long run in Nigeria;

iii. Interest rate spread has an inverse effect on the trade sector output but a positive effect on the agricultural sector output in Nigeria;

iv. Jointly, deposit money banks financing have a long term significant effect on the trade sector but does not have any effect on the agricultural sector in Nigeria.

v. There is no short run causality running from PSC, DMB, DTB and INTS to agricultural sector output; however only INTS has short run causality with trade sector output.

\section{CONCLUSION AND POLICY RECOMENDATIONS}

Based on the above findings, the study draws the conclusion that the deposit money banks financing has a long run significant effect on trade sector output but an insignificant long run effect on agricultural sector output in Nigeria. Also, deposit money banks financing have no significant short run causality running from deposit money bank financing to agricultural sector output. Lastly, in the short run, only interest rate spread has a significant influence on trade sector output in Nigeria. The study therefore provides the following recommendations:

i. In addition to making funds available to farmers, deposit money banks should also monitor the use of such funds by farmers to avoid loan diversion and consequently poor agricultural sector performance.

ii. Banks should employ research staff to conduct researches on modern approaches to effective real sector production and investments and should use the research findings to train her loan customers on the best production techniques as this will go a long way to enhance the real sector output 
iii. The spread between lending rate and deposit rate should be narrowed to trigger savings and enhance banks' loan supply and real sector loan demand which in consequent will boost productivity in the real sector.

\section{References}

Aliyu, M. \& Yusuf, A. H. (2013). Impact of private sector credit on the real sector of Nigeria. International Journal of Business and Social Research, 3(5), 105-116

Charles, A. N. B. (2012). Investigating the performance of monetary policy on manufacturing sector in Nigeria. Arabian Journal of Business and Management Review, 2(1), 12-25.

Chris, O. U., Bassey, I. I. \& Arikpo, O. F. (2014). Interest rate: A key variable in deposit money bank lending behaviour in Nigeria. Archives of Business Research, 3(4), 152-161. Doi: 10.14738/abr.34.1373.

\section{Galac, T. (2001). Early warnings of banks: Research Progress Report. Mimeo Croatian National Bank}

Honohan, P. (1997). Banking system failure in developing and transition countries: Diagnosis and production. BIS Working Paper 39.

Ikenna, O.D. (2012). Financial deregulation bounding to credit mobilization in Nigeria: A case for the real sectors and SMEs. IOSR Journal of Humanities and Social Science, 5(5), 40-59.

Kar, M. \& Pentecost, E. J. (2000). Financial development and economic growth in Turkey: Further Evidence on the Causality Issue. Loughborough University, Economic Research

Loto, M. A. (2012). Global economic downturn and the manufacturing sector performance in the Nigerian economy. Journal of Emerging Trends in Economics and Management Sciences (JETEMS), 3(1), 38-45.

Mckinnon, R. I. (1973). Money and banking in economic development: An empirical examination. Washington D. C: The Brookings Institute.

Nzotta, S. M. (2004). Money, banking and finance, theory and practice. Owerri: Hudson Jude Publishers

Ogar, A., Gabriel, E. E. \& Arikpo, O. F. (2015). The contribution of deposit money banks to the growth of the agricultural sector in Nigeria. Archives of Business Research, 3(2), 33-42, Doi: 10.14738/assrj.32.1009

Ojong, C. M., Arikpo, O. F. \& Ogar, A. (2015). The role of deposit money banks on the growth of SMEs in Cross River State, Nigeria. Journal of Social Science Research, 6 (2), 1047-1054.

Patrick, H. (1966). Financial development and economic growth in underdeveloped countries. Economic Development and Cultural Change, 174-189.

Rasheed, O. A. (2010). Interest rate determination in Nigeria. International Research Journal of Finance and Economics, 2(3), 1-12

Sagosanya, A. O. (2011). Firms growth dynamics in nigeria's manufacturing industry: A panel analysis. Journal of Applied Econometric Review, 1(1), 2-15

Sanusi, S.L. (2011). Growing Nigeria's real sector for employment and economic development: The role of Central Bank of Nigeria. Paper Delivered At The Inaugural Memorial Lecture In Honour Of Late Professor Okefie Uzoaga held on July, 12 at University of Nigeria, Nsukka, Enugu State.

Sendeniz-Yüncü, I., Akdeniz, L. \& Aydoğan, K. (2006). Interdependence of the banking sector and the real sector: evidence from OECD countries. Applied Economics, (Forthcoming).

Shaw, E. S. (1973). Financial deepening in economic development. New York: Oxford University Press.

Stephen, O. A. \& Olufemi A. A. (2015). Relevance of financial sector development on real sector productivity: 21st century evidence from Nigerian industrial sector. International Journal of Academic Research in Business and Social Sciences, 5(6), 118-132, DOI: 10.6007/IJARBSS/v5-i6/1661

Tajudeen, E. 2012. Bank credits and rural development in Nigeria (1982-2009). International Journal of Finance and Accounting. 1 (3): 45-52.

Tomola, M. O., Adedisi, T. E. \& Olawale, F. K. (2012). Bank lending, economic growth and the performance of the manufacturing sector in Nigeria. European Scientific Journal, 8(3), 19-34.

Udoh, E. \& Ogbuagu, U. R. (2012). Financial sector development and industrial production in Nigeria (1970-2009): an ARDL co-integration approach. Journal of Applied Finance \& Banking, 2(4), 49-68. 
Udoka, C. O. (2014). Sound bank lending imperative as a panacea for bad and doubtful loans in Nigeria. Euro-Asian Journal of Economics and Finance, 2(3), 176-184 